\title{
Downstream changes in DOC: Inferring contributions in the face of model uncertainties
}

\author{
Tejshree Tiwari, ${ }^{1}$ Hjalmar Laudon, ${ }^{1}$ Keith Beven, ${ }^{2,3}$ and Anneli M. Ågren ${ }^{1}$ \\ Received 17 June 2013; revised 16 November 2013; accepted 27 December 2013; published 21 January 2014.
}

[1] Dissolved organic carbon (DOC) is a central constituent of surface waters which control its characteristic color and chemistry. While the sources and controls of headwater stream DOC can be mechanistically linked to the dominant landscape types being drained, much remains unknown about the downstream controls at larger spatial scales. As DOC is transported from the headwaters to catchment outlets, the fate of stream DOC is largely dependent on the interaction of varying catchment processes. In this study, we investigated the main mechanisms regulating stream DOC in a mesoscale catchment. A landscapemixing model was used to test the role of landscapes in determining stream concentrations. The quantity of DOC lost to in-stream processes was calculated using bacterial respiration and photooxidation rates. We investigated whether there was a change in water pathways using a mass balance model and comparison of hydrology between a headwater catchment and the entire catchment. A Monte Carlo approach was used to test robustness of the model assumptions and results to uncertainty in the process parameterizations. The results indicated that during high- and intermediate-flow conditions, DOC concentrations were regulated by the contributing upstream landscape types. During base flow, the connectivity between the mesoscale river and the upstream landscape reduced resulting in large residuals in the landscape model which could not be explained by the in-stream processes. Both the mass balance model and a specific runoff comparison between upstream/downstream sites independently indicated large input of deep groundwater during base flow. Deep groundwater was important for diluting stream DOC concentrations during base flow.

Citation: Tiwari, T., H. Laudon, K. Beven, and A. M. Ågren (2014), Downstream changes in DOC: Inferring contributions in the face of model uncertainties, Water Resour. Res., 50, 514-525, doi:10.1002/2013WR014275.

\section{Introduction}

[2] Streams draining boreal forest landscapes contain some of the highest concentrations of dissolved organic carbon (DOC) in the midlatitude to northern latitude [ Laudon et al., 2012], but the question of how it is regulated across time and space remains largely unanswered. DOC plays an active role in maintaining the balance of aquatic ecosystems, primarily because of its function for stream biota [Docherty et al., 2006; Findlay et al., 2003] and biogeochemistry [Hruska et al., 2003; Kalbitz and Wennrich, 1998]. DOC has also gained attention for its role in the global carbon balance [Cole et al., 2007]. Despite the fundamental aspects of stream DOC, most research has only

Additional supporting information may be found in the online version of this article.

${ }^{1}$ Department of Forest Ecology and Management, Swedish University of Agricultural Sciences, Umea, Sweden.

${ }^{2}$ Lancaster Environment Center, Lancaster University, Lancaster, UK.

${ }^{3}$ Department of Earth Sciences, Geocentrum, Uppsala University, Uppsala, Sweden.

Corresponding author: T. Tiwari, Department of Forest Ecology and Management, Swedish University of Agricultural Sciences, SE-901 83 Umea, Sweden. (Tejshree.Tiwari@slu.se)

(C)2014. American Geophysical Union. All Rights Reserved. 0043-1397/14/10.1002/2013WR014275 been focused on understanding sources, sinks, and pathways of DOC at the headwater scale.

[3] In boreal headwater catchments, organic soils found in peatlands and forests are the main sources of stream DOC. Modeling using end-member mixing of these landscape signals has presented a conceptual approach for predicting DOC concentrations in small streams [Brooks et al., 1999; Catalán et al., 2012; Laudon et al., 2011; Reinthaler et al., 2005]. However, predicting stream concentrations at larger spatial scales using the same approach has seldom been successful [Frost et al., 2006]. These futile attempts to transfer small-scale understanding to larger scales may be linked to the challenge of capturing the different processes associated with spatial and temporal heterogeneity of larger catchments [González-Pinzón et al., 2013; Tetzlaff et al., 2010]. In addition, some processes become more dominant in lower parts of the catchment as the stream length increases. Thus, modeling DOC using small-scale processes only limits the understanding of how DOC is controlled by other processes in the downstream catchment.

[4] One such process is the increased in-channel water travel time because of longer stream lengths. This is a possible mechanism for the failure of previous model attempts using only small-scale processes. A long water travel time in the stream channel increases the potential for DOC degradation by in-stream processes such as bacterial respiration and photooxidation [Graneli et al., 1996; Larson et al., 2007]. 
Table 1. Models Used to Predict DOC Concentrations at the Krycklan Catchment Outlet

\begin{tabular}{|c|c|c|}
\hline Models & Components & Description \\
\hline Model 1 & 2 components & Till and thin + peat \\
\hline Model 2 & 3 components & $\begin{array}{l}\text { Till and thin }+ \text { peat }+ \\
\text { sorted sediments }\end{array}$ \\
\hline Model 3 & $\begin{array}{l}3 \text { components }+ \\
\text { in-stream processes }\end{array}$ & $\begin{array}{c}\text { Model } 2+\text { DOC lost to } \\
\text { bacterial respiration } \\
\text { and photooxidation }\end{array}$ \\
\hline Model 4 & $\begin{array}{c}3 \text { components }+ \\
\text { in-stream processes }+ \\
\text { deep groundwater input }\end{array}$ & $\begin{array}{l}\text { Model } 3+\text { deep ground } \\
\text { water volume input } \\
\text { calculated from mass } \\
\text { balance of BC } \\
\text { concentration fluxes }\end{array}$ \\
\hline
\end{tabular}

Both processes are largely dependent on seasonality since temperature is the main driver for bacterial respiration [Berggren et al., 2010; Reinthaler et al., 2005], and solar radiation is the driver of photooxidation [Estapa and Mayer, 2010; Tranvik and Bertilsson, 2001; Xie et al., 2004]. The combined effects of seasonality and longer in-channel water travel time on in-stream processes may lead to large losses of stream DOC concentrations at certain times of the year.

[5] Another process that changes from headwater to mesoscale is the increase in spatial and temporal variability in hydrology [Cey et al., 1998; Lyon et al., 2012; Pacific et al., 2010]. Schmidt and Hahn [2012] made a distinction between shallow pathways for water which are influenced by surface processes and deep pathways that have no recent surface influences and have a longer transit time through the soil and bedrock. In general, boreal headwater streams are fed by shallow pathways with chemistry that closely reflect surface processes such as those occurring in the riparian zone [Bishop et al., 2004; Grabs et al., 2012]. In contrast, streams of the mesoscale catchment are fed by a combination of both shallow and deep pathways. The combination of these sources determines the downstream chemistry [Hagedorn et al., 2000], which vary not only with catchment size but also with season and runoff conditions. For instance, deeper pathways are important for maintaining runoff during base flow conditions [Hinton et al., 1998; Krause et al., 2007; Maurice et al., 2002], whereas more shallow pathways likely become more important at high flow. One key to understanding how stream DOC concentrations are regulated in the mesoscale catchment therefore lies in understanding, separating, and quantifying the hydrological pathways.

[6] Natural geochemical tracers are a widely used technique for tracing flow paths within catchments [Tetzlaff et al., 2008]. They can be used as a diagnostic tool to determine how river basins function at different spatial scales [Soulsby and Dunn, 2003; Uhlenbrook et al., 2002]. Base cations (BCs) are a semiconservative tracer which has been used to determine if there is a partition of water sources in streams and rivers [Burns et al., 1998; Dunn et al., 2010; Soulsby et al., 2011]. The BC concentrations are commonly much lower in shallow groundwater compared to deep groundwater as the $\mathrm{BC}$ concentration primarily is regulated by water residence time in the subsurface environment [Garrett et al., 2012; Klaminder et al., 2011; Wolock et al., 1997]. This difference in BC concentration between shallow flow and deep flow paths provides an opportunity to determine the sources of water in mesoscale catchment.
[7] In light of the dominant roles of landscape processes, in-stream processes, and the role of hydrology in the catchment, we investigate how DOC is regulated at the mesoscale. The question we asked was if the downstream DOC concentration in a 6790 ha catchment is the sum of all contribution parts or if there are other regulatory mechanisms that need to be accounted for. The challenge of this study was to bridge the knowledge gap between stream DOC variability at small scales to those observed at larger spatial scales using the following questions: (1) Do shallow hydrological pathways from peatland and forest landscapes explain all of the variability in DOC concentrations at the outlet of the mesoscale catchment? (2) Can the model be improved by adding more landscape end-members; in this case can sorted sediments' landscapes be used to improve DOC prediction at the outlet of the mesoscale catchment? (3) Are in-stream processes responsible for the lower DOC concentrations found at the outlet of the mesoscale catchment? (4) Is there a change in hydrological pathways during base flow and can it be used to predict DOC concentrations in the mesoscale catchment? These modeling steps are summarized in Table 1. In making inferences about the processes that explain DOC variability, we have also assessed the uncertainties associated with the model assumptions used to estimate deep groundwater volume (Model 4).

\section{Method}

\subsection{Site Description}

[8] The Krycklan boreal forest watershed is a 6790 ha experimental catchment located in northern Sweden. The catchment is composed of 18 monitored catchments [ Laudon et al., 2011] but can be further divided into 115 nested subcatchments varying in sizes from 4 to 6790 ha (S1, see supporting information). The bedrocks consist of Svecofennian rocks with different proportions of metasediments/ metagraywacke (94\%), acid and intermediate metavolcanic rocks $(4 \%)$, and basic metavolcanic rocks $(3 \%)$. Quaternary deposits (dominated by till) cover the upper parts of the watershed, while postglacial sediments (dominated by silt) cover the lower part of the catchment (Table 2). The large deposits of postglacial sediments found in the lower catchment are the result of a postglacial delta which covered an esker that followed the Vindeln River for approximately $143 \mathrm{~km}$. Forest $(87 \%)$ and peatlands $(9 \%)$ dominate the landscape with smaller portions of lake coverage $(\sim 1 \%)$. The forest standing stock consists of Pinus sylvestris (63 vol \%), Picea abies ( $27 \mathrm{vol} \%)$, and deciduous forest stands $(10 \mathrm{vol} \%)$. The main land uses within the watershed are forestry (87\%) and agriculture (1\%).

\subsection{Stream Water Sampling}

[9] The Krycklan catchment has been a part of a continuous monitoring program for many years, which provides a compilation of water chemistry [Laudon et al., 2013; Oni et al., 2013]. In this study, four years (2006-2010) of data obtained from the outlet of four catchments $(\mathrm{C} 2, \mathrm{C} 4, \mathrm{C} 16$, and $\mathrm{C} 20$ ) were used to create the landscape-mixing model (Figure 1). This provided data from 111 concurrent sampling occasions for each stream. The water samples were collected every fortnight except during the snowmelt or heavy rainfall events when sampling occurred more frequent (2-3 times 
Table 2. Surficial Geology Within the Krycklan Catchment and Subcatchments

\begin{tabular}{lcccc}
\hline Catchments & Size (ha) & $\begin{array}{c}\text { Till and } \\
\text { Thin (\%) }\end{array}$ & Peat (\%) & $\begin{array}{c}\text { Sorted } \\
\text { Sediments (\%) }\end{array}$ \\
\hline C2 & 12 & 100 & 0 & 0 \\
C4 & 18 & 49 & 51 & 0 \\
C7 & 47 & 81 & 19 & 0 \\
C16 & 6891 & 58 & 9 & 30 \\
C20 & 145 & 21 & 12 & 65 \\
\hline
\end{tabular}

per week). During winter, monthly sampling was conducted. Samples were collected in acid-washed and stream-rinsed high-density polyethylene bottles and kept in cold storage until analysis [Buffam et al., 2007]. In the laboratory, DOC concentrations were analyzed using a Shimadzu TOC- $V_{\mathrm{CPH}}$ analyzer after acidification to remove inorganic compounds. No significant difference between filtered and unfiltered samples was found which indicated that particulate organic carbon was minimal in the stream waters [Laudon and Buffam, 2008]. The samples were also analyzed for BCs (defined as $\sum \mathrm{K}^{+}, \mathrm{Mg}^{2+}, \mathrm{Na}^{+}, \mathrm{Ca}^{2+}$ ) using ICP-OES (inductively coupled plasma optical emission spectroscopy) on a Varian Vista Ax Pro instrument (see Buffam et al. [2007] for a summary of analysis).

\subsection{Discharge Measurements}

[10] Runoff measurements from two catchments: a smaller headwater catchment $(\mathrm{C} 7 ; 45$ ha) and the catchment outlet (6790 ha; C16) were used in this study (Figure 1). The stage height at C7 was determined from a $90^{\circ} \mathrm{V}$ notch in a heated weir house with a pressure transducer connected to a Campbell Scientific data logger [Laudon et al., 2013]. The stage height at the outlet (C16) was measured with an OTT RLS radar level sensor (Low-power radar technology for noncontact water level measurements) located above the surface of the stream [Nathanson et al., 2012]. Hourly stage height was recorded at both sites, and established rating curves were used to calculate the daily discharge at each catchment. At C7, the rating curve was established using salt dilution technique and bucket-method measurements [Laudon et al., 2004a]. At C16, the rating curve was determined using a fluid mechanic based model constrained with topographic data from an airborne light detection and ranging (LIDAR) scan [Nathanson et al., 2012]. Four years (2006-2007) of discharge data at C7 were used for the in-stream processing calculations and the mass balance calculation. The discharge data compiled for 202 days during April-October in 2010 for both catchments (C7 and C16) were used for the comparison of hydrological pathways (section 2.8). The discharge for both catchments was converted to specific discharge using the area (ha) for the headwater catchment and the entire catchment.

\subsection{Landscape Analysis}

[11] Watershed delineation of the Krycklan catchment was created using a combination of LIDAR measurements,

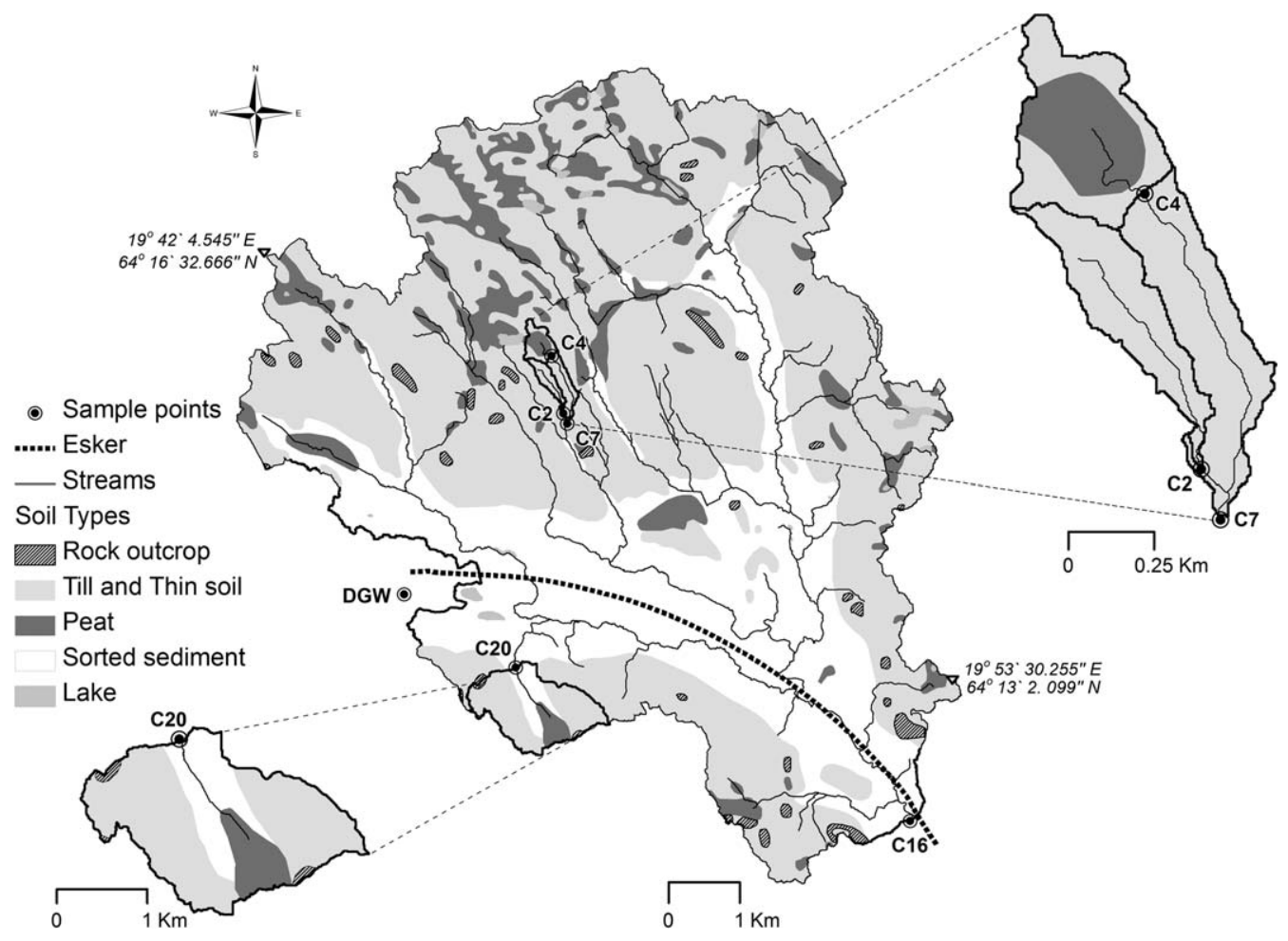

Figure 1. Subcatchments, sample points, and quaternary deposits within the Krycklan catchment. C2, $\mathrm{C} 4$, and C20 are headwater catchments used as end-members to model concentration at C16. Discharge measurements were conducted at site C7 and C16. DGW is the location of the deep groundwater sampling point. 
gridded digital elevation model (DEM), and field observations. A $5 \mathrm{~m}$ resolution DEM was created from LIDAR measurements. Sinks on the DEM were removed, streams were created, and watersheds were delineated using the hydrological toolbox in ArcGIS 10.0. The correction of bridges and road culverts were made manually to match field conditions by a professional cartographer and field surveys. The quaternary deposit map $(1: 100,000)$ from the Geological Survey of Sweden (SGU, Uppsala, Sweden) was used to estimate the surficial geology percentage (hereinafter referred to as landscape type), specifically the proportion of till, peat, bedrock outcrops, sand, silt, and glaciofluvial sediments within each subcatchments (Figure 1) [Agren et al., 2010].

\subsection{Landscape-Mixing Model}

[12] Headwater catchment landscapes are drained by shallow groundwater pathways. The chemistry at the catchment outlet reflects the chemistry in landscape types being drained. Laudon et al. [2011] used a landscape-mixing model to successfully predict DOC concentrations in mixed catchments up to a size of 700 ha by mixing stream concentrations of dominant landscape types (till and thin soils and peat soils) in proportion to their landscape percentages (Table 1, Model 1). Using this approach, a third landscape end-member (sorted sediments) was included in the model to determine DOC concentrations at the outlet of the Krycklan catchment (C16; Table1, Model 2). Thus, headwater chemistry from dominant landscape types within the Krycklan catchment were used as end-members [Ägren et al., 2007; Buffam et al., 2008] to model DOC concentrations $\left(\mathrm{mg} \mathrm{L}^{-1}\right)$ at the catchment outlet $\left(D O C_{\text {Outlet }}\right.$; equation (1)).

$$
D O C_{\text {Outlet }}=A \times D O C_{\text {Peat }}+B \times D O C_{\text {Till }}+C \times D O C_{\text {Sorted Sediments }}
$$

where $A, B$, and $C$ represent the aerial coverage of the quaternary deposits (in proportion) within the catchment assuming that the specific discharge is the same. $D O C_{\text {Peat }}$, $D O C_{\text {Till }}$, and $D O C_{\text {Sorted Sediments }}$ are the DOC concentrations $\left(\mathrm{mg} \mathrm{L}^{-1}\right)$ measured at headwater catchments outlets draining the respective landscape type taken during the 111 sampling occasions. The subcatchment $\mathrm{C} 2$ was used for the forested till and thin end-member since forested till covers $100 \%$ of the catchment. For peat end-member, C4 was used, where $97 \%$ of the water passes through a peatland before entering the stream, and for the sorted sediment endmember, the subcatchment C20 was used where $80 \%$ of water passes through the sorted sediments before entering the stream. Since the majority of water draining these catchments is influenced by the respective landscape types, it was assumed that these catchments were representative signals. Rocks, arable lands, and lakes, which make up less than $3 \%$ of the landscapes, were not found as contributing sources of DOC. Including these landscape types did not improve the model fit, but it increased the uncertainty of the model. Therefore, their contributions were set as zero in the model [Agren et al., 2013].

\subsection{In-stream Processing}

[13] In large catchments, the longer in-channel travel time of water increases the exposure of DOC to in-stream processes resulting in the transformation of DOC to carbon dioxide, dissolved inorganic carbon, and particulate organic matter. To show this effect on DOC concentrations in the Krycklan catchment, the in-channel water travel time was determined using the distribution of stream lengths obtained from the high-resolution DEM and the discharge of a headwater catchment (C7) scaled to 115 subcatchments in Krycklan (S1, see supporting information). From the distribution, the median stream length was used in the stream slope-base regression model [Wallin et al., 2013] to determine the in-channel travel time per meter. The inchannel water travel time was scaled entire stream network for the bacterial respiration calculations and for third- and fourth-order streams for the photooxidation calculations. Small first- and second-order streams were excluded from the photooxidation calculation since it was assumed that they were shaded by trees.

\subsubsection{Bacterial Respiration}

[14] Berggren et al. [2010] showed low bacterial respiration rate $\left(16 \mu \mathrm{g} \mathrm{L}^{-1} \mathrm{~d}^{-1}\right)$ at low temperatures $\left(0^{\circ} \mathrm{C}\right)$ and increased respiration rate $\left(96 \mu \mathrm{g} \mathrm{L}^{-1} \mathrm{~d}^{-1}\right)$ at higher temperatures $\left(25^{\circ} \mathrm{C}\right)$ in a forest-dominated headwater catchment in Krycklan. Using this relationship (equation (2)) and the median in-channel water travel time $(R T)$ of the entire stream, the total DOC lost to bacterial respiration $\left(B_{d}\right)$ was determined (equation (3)), where $t$ is the water temperature and $B_{r}$ is the DOC lost to bacterial respiration.

$$
\begin{gathered}
B_{r}=16^{0.00717 t} \\
B_{d}=B_{r} \times R T
\end{gathered}
$$

\subsubsection{Photooxidation}

[15] The DOC lost to photooxidation $\left(P_{d}, \mathrm{mg} \mathrm{L}^{-1}\right)$ was quantified using the product of photochemical oxidation rate $\left(P_{r}, 1.1 \mathrm{mg} \mathrm{C} \mathrm{L}^{-1} \mathrm{~d}^{-1}\right)$ [Köhler et al., 2002] and the median in-channel travel time ( $R T$, days) of third- and fourth-order streams (equation (4)). Winter period (midNovember to mid-April), when the streams are covered by ice and snow, was not included in the calculations. The cloudy days in summer could not be excluded from the analysis; thus, it consequently contributes to the uncertainty in estimating the DOC lost to photooxidation.

$$
P_{d}=P_{r} \times R T
$$

[16] The sum of DOC loss by bacterial respiration and photooxidation showed the total loss of DOC to in-stream processing. This was subtracted from the modeled concentrations to show the effects of in-stream processes on DOC concentration at the catchment outlet (Table 1, Model 3).

\subsection{Mass Balance Model}

[17] Deep groundwater is characterized by deeper pathways and longer water residence time within the catchment. This results in greater weathering rates because of increase subsurface contact time with mineral soils and bedrock. BC concentrations are therefore much higher in groundwater than in receiving streams [Klaminder et al., 2011]. Assuming that there is a mixture of two distinct sources of water at the catchment outlet (shallow and deep pathways), a mass balance model was used to determine the influence of deep groundwater input on DOC concentrations in the 
Krycklan catchment (C16; equation (5)). The base cations were used as a semiconservative tracer in the mass balance model assuming that any gain or loss of concentrations in surface water concentrations can be identified and quantified using deep groundwater [Kalbus et al., 2006]. Shallow groundwater concentrations were modeled using the landscape-mixing model as outlined for DOC. Assuming that measured BC fluxes at the outlet of the catchment are the sum of shallow groundwater and deep groundwater fluxes, a mass balance model was used to determine the quantity of deep groundwater for each sample.

$$
C_{M e a} V_{M e a}=C_{S G W} V_{S G W}+C_{D G W} V_{D G W}
$$

where $C$ is the DOC concentration $\left(\mathrm{mg} \mathrm{L}^{-1}\right), V$ is the discharge volume $\left(\mathrm{m}^{3}\right)$, subscript $M e a$ is the measured component, subscript $S G W$ is the modeled shallow groundwater components, and subscript $D G W$ is the deep groundwater components. Equation (5) can be solved for the deep groundwater volume $V_{D G W}$ giving equation (6).

$$
\begin{gathered}
V_{D G W}=\frac{\left(C_{M e a}-C_{S G W}\right)}{\left(C_{D G W}-C_{S G W}\right)} \times V_{M e a} \\
V_{S G W}=V_{M e a}-V_{D G W}
\end{gathered}
$$

[18] The difference of the measured discharge volume $\left(V_{M e a}\right)$ and the estimated deep groundwater volume $\left(V_{D G W}\right)$ was assumed as the shallow groundwater volume $\left(V_{S G W}\right.$; equation (7)). The $V_{M e a}$ is the measured discharge at $\mathrm{C} 7$ scaled for the entire catchment (section 2.3). The $V_{S G W}$ and $V_{D G W}$ were used as end-members in the mass balance model to recalculate the modeled DOC $\left(C_{S G W}\right.$; Model 4; Figure 2). Deep groundwater concentrations $\left(C_{D G W}\right)$ in the equation were obtained from a well which is used as a groundwatermonitoring site by the SGU. The well is located $120 \mathrm{~m}$ outside of the catchment but within the same geological deposit, i.e., the esker covered by postglacial sandy/sorted sediment (Figure 1). We assumed that the chemistry in the well and in the deep groundwater at the catchment outlet was similar based on the similarity in soil type and geology.

\subsection{Hydrological Pathways}

[19] The hydrology of the catchment was also investigated to determine if there was a change in pathways within the catchment. This was done by comparing the specific discharges of a small headwater catchment (C7) with that of the entire catchment (C16; section 2.3). The $\mathrm{C} 7$ catchment is small $(<45 \mathrm{ha})$ and drained by first- and second-order streams. It is assumed to be representative of the shallow pathways. The large-scale catchment (C16) which is drained by a combination of first- to fourth-order streams is assumed as the integrated signal of both shallow pathways and deeper pathways. If the same processes operate at both the small and large scales, then the difference in specific discharges should be negligible. The difference in specific discharge during base flow, between $\mathrm{C} 16$ and $\mathrm{C} 7$, is consequently assumed to be due to the contribution of deep groundwater.

\subsection{Uncertainty Calculations}

\subsubsection{Mass Balance Model Uncertainty}

[20] In short, the results of the mass balance model are subjected to uncertainties in the model components
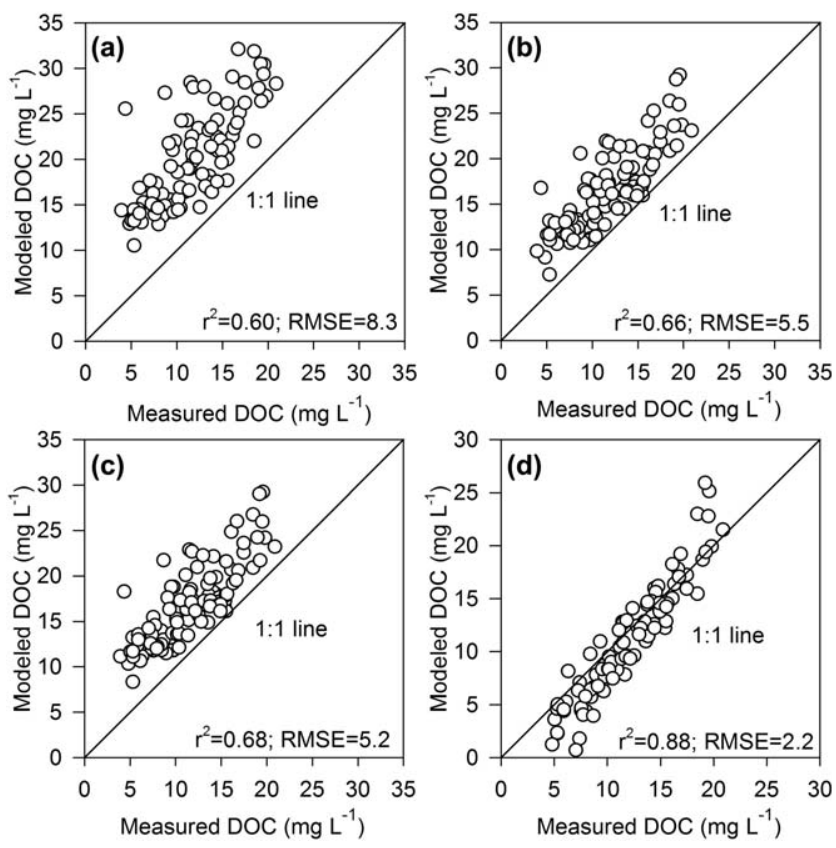

Figure 2. DOC concentration at the Krycklan catchment outlet during 2006-2010 modeled using (a) a twocomponent landscape-mixing model (Model 1), (b) a threecomponent landscape-mixing model (Model 2), (c) the three-component landscape-mixing model including instream processes (Model 3), and (d) the three-component landscape-mixing model including in-stream processing and deep groundwater influence (Model 4).

(modeled concentrations, measured concentrations, deep groundwater concentrations, and specific discharge). Uncertainties in the model output (percent deep groundwater volume, Figure 5a) were determined by propagating the coefficient of variation $((\mathrm{CV})$ standard deviation divided by mean) of the model components using a Monte Carlo approach. The small uncertainties in the catchment sizes were considered negligible and excluded from the analysis. The uncertainty (Table 3 ) of each component was used to create a distribution around the actual measured value [Joerin et al., 2002] assuming that they were normally distributed and independent of each other. Specifically; repeated measurements of $\mathrm{BC}$ concentrations (instrument variability) were used as the uncertainty in the measured concentrations [Buffam et al., 2007] (Table 3, A). The uncertainty in the shallow groundwater concentrations were determined by propagating measured concentration uncertainty (instrument variability) for the three landscape types (till and thin, peat, sorted sediment). In addition to this, the uncertainties from the in-stream processing were also propagated [Berggren et al., 2010; Köhler et al., 2002] and added into the uncertainty for the shallow groundwater component (Table 3, B). Since there were no data on instrument uncertainty for the deep groundwater concentration, the CV in the data set was used to represent the sampling variability as a conservative measure (Table $3, \mathrm{C})$. This is probably an overestimation of the sampling variability because it introduces temporal variation in the data set; however, deep groundwater chemistry is assumed to be more stable than shallow groundwater chemistry. The 
Table 3. Coefficient of Variation (CV) Used to Model Uncertainty in the Mass Balance Model (A-D) and the Comparison of Hydrology Model (D-E)

\begin{tabular}{|c|c|c|c|}
\hline & Model Components & $\mathrm{CV}$ & Source \\
\hline A & Measured BC $\left(\mathrm{mg} \mathrm{L}^{-1}\right)$ & $2 \%$ & Repeated analysis using ICP analyzer \\
\hline B & Modeled BC $\left(\mathrm{mg} \mathrm{L}^{-1}\right)$ & $3.7 \%$ & $\begin{array}{l}\text { Propagation of measured } \mathrm{BC} \text { variability and in-stream } \\
\text { processing coefficient of variation }\end{array}$ \\
\hline $\mathrm{C}$ & Groundwater BC $\left(\mathrm{mg} \mathrm{L}^{-1}\right)$ & $15 \%$ & Coefficient of variation from deep groundwater data set \\
\hline $\mathrm{D}$ & Discharge C7 $\left(\mathrm{mm} \mathrm{d}^{-1}\right)$ & $5 \%$ & Comparison of manual and rating curve estimated discharge \\
\hline $\mathrm{E}$ & Discharge $\mathrm{C} 16\left(\mathrm{~mm} \mathrm{~d}^{-1}\right)$ & $9 \%$ & Comparison of manual and rating curve estimated discharge \\
\hline
\end{tabular}

uncertainty in discharge at C7 was determined by comparing manual instantaneous measurements (from salt dilution and bucket measurements) and the estimated discharge derived from the rating curve [Laudon et al., 2004b] (Table $3, \mathrm{D})$.

[21] For the Monte Carlo analysis, components were randomly sampled from the assumed normal distribution created using the variability around the 111 observations. The sampled components were then used to compute deep groundwater volume 10,000 times. The coefficient of variation of the simulated values for each time step was used to represent the uncertainty. The upper and lower confidence limits $(95 \%)$ of the coefficient of variation were fitted onto the estimated deep groundwater volume against discharge regression curve (Figure 5a).

\subsubsection{Discharge Uncertainties}

[22] The uncertainties in deep groundwater volume estimated from the differences in specific discharges between two catchments were also determined using Monte Carlo analysis. The main sources of uncertainties in the specific discharges measured at $\mathrm{C} 7$ were determined from the difference of the manual instantaneous measurements and the estimated discharge from the rating curves (Table 3, D and E) [Laudon et al., 2004b]. The uncertainty resulting from unknown water losses that bypass the weirs was considered negligible and was not included. The uncertainty in specific discharge at $\mathrm{C} 16$ was determined by comparing specific discharge generated by two different methods. Discharges derived from empirical rating curve (developed from observation data) and discharge derived from a LIDAR model rating curve comparison showed a 9\% difference during high flow and smaller difference during base flow [Nathanson et al., 2012]. As a conservative measure, 9\% was used to represent the variability in discharge at $\mathrm{C} 16$ for this analysis (Table 3, E). The specific discharge data for both sites were log-transformed to create normally distributed data sets. Random sampling was repeated until 10,000 values were compiled for each site. The coefficient of variation for each time step was determined and plotted as the uncertainty (Figure 5b).

\section{Results}

\subsection{Landscape-Mixing Model}

[23] The three end-member (till and thin, peat, sorted sediments (Model 2; Figure 2b)) landscape-mixing model (equation (1)) predicted DOC concentrations at the Krycklan catchment outlet with an RMSE of $6.1 \mathrm{mg} \mathrm{L}^{-1}$ and $R^{2}=0.64, p<0.0001$ (Figure 2b). These values showed an improvement from Laudon et al. [2011] twocomponent mixing model (till, peat (Model 1; Figure 2a)) which had an RMSE values of $9.1 \mathrm{mg} \mathrm{L}^{-1}$ and $R^{2}=0.56$, $p<0.0001$. However, Model 2 still overpredicted DOC concentrations. Sorted sediments end-member improved the DOC model, but it could not explain all the variability in DOC concentrations at the catchment outlet.

\subsection{In-stream Processes}

[24] Investigating in-stream processes by first calculating in-channel water travel time showed a relationship which varied with discharge. For the entire stream network, the in-channel travel time varied from approximately 2 days during base flow to $6 \mathrm{~h}$ during high flow. The in-channel travel time of the third- and fourth-order streams (used for calculations of photooxidation) ranged from approximately 5 to $17 \mathrm{~h}$ depending on the flow conditions.

[25] An average of $0.024 \mathrm{mg} \mathrm{L}^{-1}$ of DOC lost to bacterial respiration was estimated using the in-channel water travel time of the entire catchment. Maximum DOC loss was $0.09 \mathrm{mg} \mathrm{L}^{-1}$ during low flow $\left(<0.06 \mathrm{~mm} \mathrm{~d}^{-1}\right)$. Using in-channel travel time of third- and fourth-order streams resulted in average DOC loss by photooxidation of $0.48 \mathrm{mg}$ $\mathrm{L}^{-1}$. In total, both processes accounted for a loss of $0.5 \mathrm{mg}$ $\mathrm{L}^{-1}$ of DOC. These results suggest that in-stream processes removed less than $1 \mathrm{mg} \mathrm{L}^{-1}$ of DOC per day. Subtracting the losses of DOC from the modeled concentrations resulted in a model that still overpredicted DOC concentrations (Model 3; Figure 2c). Therefore, DOC concentrations remained higher than measured concentrations suggesting that other factors should be responsible for regulating DOC which was not captured in the surface water processes.

[26] Lakes in total represented less than $1 \%$ of the catchment and were not included in these calculations. We measure DOC at one of the headwater lake outlets (C5) [Buffam et al., 2007] where the lake signal, i.e., lower DOC due to longer residence times, can be detected. However, following the stream down toward the outlet, the lake signal can only be traced to the next station $1.3 \mathrm{~km}$ downstream. Further downstream, mixing with other sources of water distorts the lake signal before reaching the catchment outlet [Agren et al., 2007; Buffam et al., 2007; Laudon et al., 2011]. Since most of the small lakes are situated in the upper parts of the catchment, it was therefore assumed that the lake effect on DOC measured at the outlet was negligible. We assume that the lake effect does not affect the model significantly at the outlet. However, determining the residence time in lakes can provide useful information for future modeling of DOC at headwater scale.

\subsection{Inferred Deep Groundwater Input}

[27] Comparing modeled (Model 3) and measured concentrations of DOC over time showed large differences 


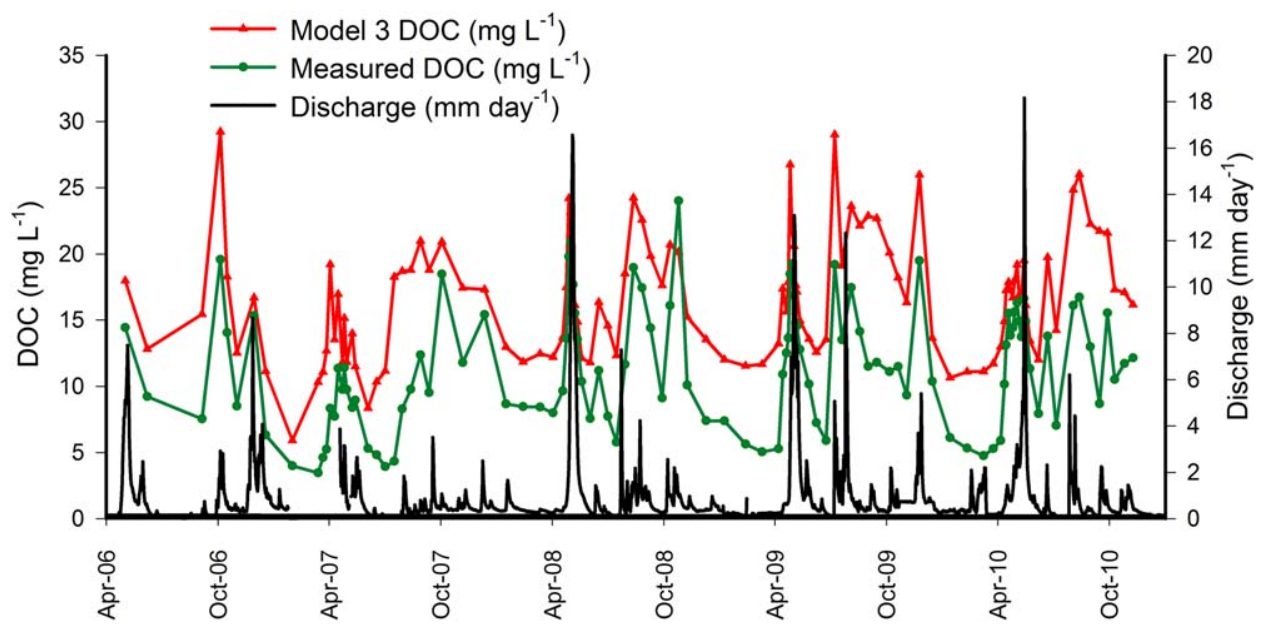

Figure 3. Measured DOC and modeled DOC (three-component and in-stream processing, i.e., Model 3) in relation to discharge measured at the outlet of the Krycklan catchment.

particularly during low discharges (Figure 3) even after including in-stream processing. Analysis of the residuals also showed a systematic difference with flow, where the highest residual occurred during low-flow conditions. One suggestion was that changing hydrological pathways during high- and low-flow situations could be a mechanism to explain why the landscape-mixing model performed less well during low flow conditions.

[28] Testing this assumption using the mass balance of BC fluxes showed approximately $80 \%$ of deep groundwater volume during lowest discharge (Figure 5a). The results indicated that deep groundwater influx was high during base flow but decreased at higher discharge levels. These results of estimated deep groundwater volume were used to develop a regression model. This regression model was then used to obtain the deep groundwater end-member for the DOC model flux. Applying the mass balance with the deep groundwater volume estimated DOC concentrations leads to an improved model fit $\left(R^{2}=0.88, p<0.0001\right.$, and RMSE $=2.2$ (Model 4; Figures 2d and 6)).

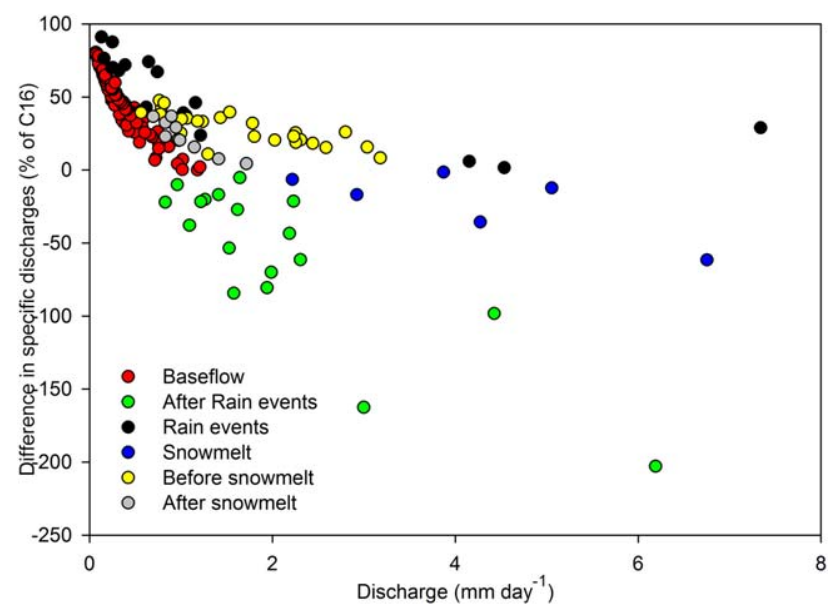

Figure 4. The differences in specific discharges between $\mathrm{C} 7$ and $\mathrm{C} 16$ are shown as percentage of the specific discharge in $\mathrm{C} 16$.
[29] As an independent estimate of deep groundwater influence, we compared the specific discharge of the headwater catchment (C7) with that of the entire catchment (C16). The two sites showed large differences, especially during low flow with higher specific discharge at the 6790 ha outlet (C16) compared to the 45 ha headwater catchment (C7). Analysis of the residuals showed large variation during high discharges (Figure 4); however, during low flow a systematic trend was observed (Figure $5 \mathrm{~b}$ ). The differences plotted in percentage showed an $80 \%$ residual during low flow conditions $\left(<0.06 \mathrm{~mm} \mathrm{~d}^{-1}\right)$ which decreased systematically with increasing discharge (Figure $5 b$ ). This corroborates the results from the mass balance approach. There was $80 \%$ more water in the large catchment compared to its headwater catchment suggesting another source of water during base flow.

\subsection{Uncertainty Analysis}

[30] The uncertainties in the calculated deep groundwater are shown as gray lines (Figure 5). Both of the methods used, mass balance (Figure 5a) and comparison of hydrology (Figure 5b), were more uncertain during high
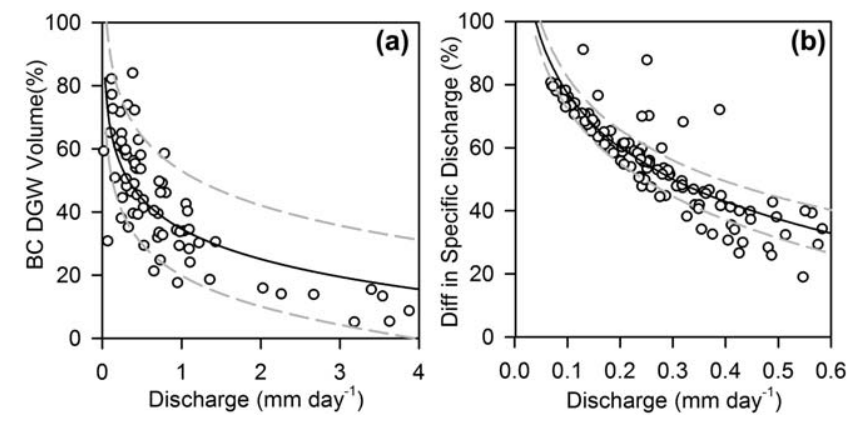

Figure 5. (a) Discharge ascribed to deep groundwater calculated from mass balance of base cation (BC) fluxes and (b) difference in specific discharges between the headwater catchment $(\mathrm{C} 7)$ and the entire catchment $(\mathrm{C} 16)$. The gray dashed lines are the uncertainty calculated from the $95 \%$ confidence interval of the coefficient of variance of the models. 
flow. However, during low flow which is when the importance of the deep groundwater flow paths becomes relatively more important, the uncertainties were low (17\% for mass balance and $7 \%$ comparison of hydrology). The large variability in the uncertainty data set reflects the complexity of hydrological data. Large spread in the data set can be explained by flashiness in discharges, difference in flow regimes, and lag effects caused by the travel time distributions from headwater to catchment outlet. This can be observed in the residual plot which shows both large negative and positive values (Figure 4). During high flow, the strong positive outliers occur at the beginning of snowmelt when the specific discharge at C16 is higher than that at C7. Rain events during base flow and high flow showed strong positive outliers, while the catchment responses after rain events resulted in negative residuals. During snowmelt, residuals were close to zero but increased as flow receded. In the base flow period, less scatter was observed.

\section{Discussion}

[31] Investigating the mixing of shallow groundwater from landscapes, in-stream processes, and the changes in groundwater pathways provides a temporally explicit tool for understanding DOC regulation in the mesoscale catchment. DOC shifts from being regulated by shallow pathways of the contributing landscapes at high and intermediate discharges, to being controlled by deeper groundwater pathways during low discharges. In this study, we showed how DOC concentrations are affected by these catchment processes as it moves from the sources in the headwaters to the catchment outlet.

[32] Different landscape types generate different DOC stream concentrations [Creed et al., 2008; Evans et al., 2006]. DOC produced in the headwater catchments from forest and peatland soils is flushed into streams by rain and snowmelt episodes [Hornberger et al., 1994]. These highdischarge events result in increased connectivity between streams and soils in the entire catchment, including the source areas [Bracken and Croke, 2007]. As such, landscape heterogeneity is one of the main mechanisms controlling stream DOC variability [Aitkenhead et al., 1999; Jencso et al., 2009; Nippgen et al., 2011]. Using this concept, Laudon et al. [2011] showed that it was possible to predict stream DOC concentrations in downstream catchments by simply mixing the forest and peatland landscape signals in proportion to their different landscape percentage. However, as DOC was transported further downstream, the ability to predict the river concentrations with the major landscapes signal only was reduced (Model 1; Figure 2a). One assumption was that the change in landscape types to more sedimentary soils, in the lower parts of the larger catchment, influenced the DOC concentration. Sedimentary soils usually export lower DOC concentrations, than peat and till soils, because of the high specific surface area that adsorb DOC to the mineral surfaces [ Kalbitz et al., 2003]. Although including the sorted sediments in the landscape-mixing model improved the prediction (Model 2; Figure 2b), the DOC concentrations remained overpredicted. This suggested that the DOC at the mesoscale was regulated by factors other than shallow hydrological flow paths alone.
[33] Further investigations of the landscape-modeled concentrations showed a systematic overprediction at high and low flows with the largest overprediction occurring during low flows (Figure 3). Low flows are synonymous with longer water travel times which increases the potential for in-stream processes on stream DOC concentrations [Benner and Opsahl, 2001; Bertilsson and Tranvik, 2000; Hrachowitz et al., 2009]. The in-channel water travel time increased from a few hours at high flow to approximately 2 days during base flow. While previous studies [Farjalla et al., 2009; Sobczak et al., 1998; Ziegler and Brisco, 2004] have shown the importance of DOC removal by bacterial respiration and photooxidation, our study suggests that this was not quantitatively important. There was a small estimated average daily loss of DOC by bacterial respiration $\left(0.02 \mathrm{mg} \mathrm{L}^{-1} \mathrm{~d}^{-1}\right)$ and photooxidation $(0.43 \mathrm{mg}$ $\mathrm{L}^{-1} \mathrm{~d}^{-1}$ ) totaling a loss of less than $1 \mathrm{mg} \mathrm{L}^{-1} \mathrm{~d}^{-1}$. Despite our calculated in-channel water travel time being a measure of the maximum water travel time within the stream network [Wallin et al., 2013], this loss by in-stream processing was not large enough to influence the modeled DOC concentrations (Model 2), which were still overpredicted by $5.2 \mathrm{mg} \mathrm{L}^{-1}$ (Model 3).

[34] Since neither the landscape signals nor in-stream processes could explain the variability of DOC during low flow in the downstream mesoscale catchment, we turned the attention to the role of hydrological pathways. Hood et al. [2006] showed that as the catchment scales up from headwater to the mesoscale, there are greater contributions from deeper groundwater with longer hydrological pathways flowing through more mineral soils. As the stream flow recedes, this deeper groundwater could become the dominant contributor to stream discharge at the catchment outlet [Covino and McGlynn, 2007; Langhoff et al., 2006; Payn et al., 2012]. Hence, a change from shallow pathways to deeper ones during base flow could help explain our inability to model the DOC concentrations using only surface processes.

[35] The results of the mass balance of $\mathrm{BC}$ concentration fluxes and the comparison of hydrology both supported the assumption of large input of deep groundwater during base flow. Both methods estimated the deep groundwater volume to $80 \%( \pm 7 \%)$ and $81 \%( \pm 17 \%)$, respectively, during base flow. The mass balance method suggested that large input of deep groundwater with different chemistry than surface water influences stream chemistry during base flow. The difference in specific discharges during base flow suggests that water originates from sources other than what arrives from the headwaters.

[36] With two independent methods showing deep groundwater input in the Krycklan catchment during base flow, we gain new insights of how DOC is regulated at the larger mesoscales. Deep groundwater has low DOC concentrations compared to surface water concentrations [Hood et al., 2006]. During base flow, the large influx of deeper groundwater in the catchment results in a dilution of the DOC produced by the upland landscapes. Including deep groundwater in the final modeling step (Model 4; Figure 2d) for predicting DOC concentrations at the catchment outlet improved the model fit (Figure 6). This indicated that when the hillslope and stream network are unconnected during base flow, the subsurface flow from shallow pathways is not 


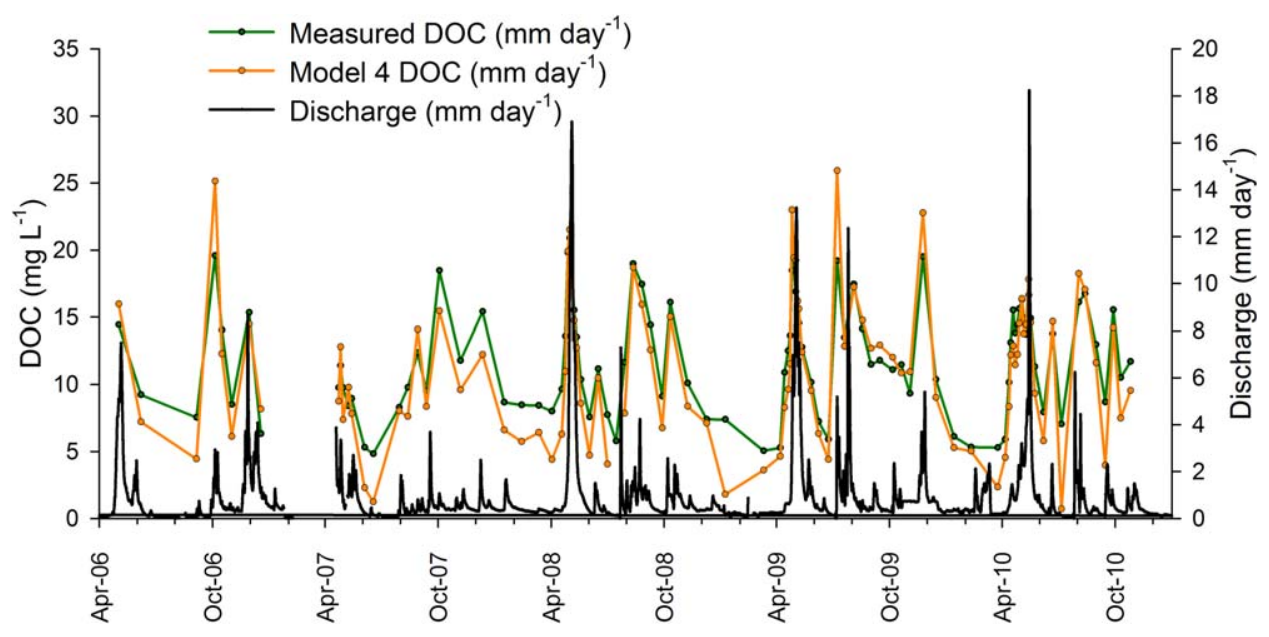

Figure 6. Measured DOC and Model 4 DOC in relation to discharge at the outlet of the Krycklan catchment.

the main regulator of stream chemistry. Additionally, the small loss of DOC to in-stream processes indicated that deep groundwater input is more influential at regulating stream chemistry than in-stream processes in boreal catchments of this type. However, it is plausible that in catchments with lower DOC, the relative importance of in-stream processing may be greater.

[37] Uncertainties in both models were much lower during base flow than during high flow. The uncertainties in the mass balance model reflected the increased spatial and temporal variation in the $\mathrm{BC}$ concentrations during higher flows. The high uncertainty reflects the difficulty in adequately representing chemistry for the entire catchment using deep groundwater data from a single well, as well as reflecting all the variability in the catchment using few headwater chemistry [Cooper et al., 2000; Evans et al., 2006]. Uncertainties in the output of the discharge comparison are a result of the different hydrological responses of C7 and C16 to wetting-up and drying-down. Tracing hydrological flow paths using specific discharges is challenged by different catchment responses to events. For instance, snow melts earlier at lower elevation close to the outlet (C16 is at $128 \mathrm{~m}$ above sea level (asl)) than at the headwaters ( $\mathrm{C} 7$ is at $237 \mathrm{~m}$ asl) resulting in an earlier peak in discharge. The steeper slope of $\mathrm{C} 16$ causes the catchment to respond more rapidly to rain events. Additionally, the larger area of alluvial-sorted sediments in C16 causes faster runoff than in $\mathrm{C} 7$ because of more transmissive soils, compared to the headwater catchment that are primarily underlain by moraine (till and thin soils) and peat soils. Even though the assumptions made in the mass balance model and the comparison of hydrology introduced uncertainties to the model outputs, these uncertainties were not enough to explain the large residuals during base flow and the small residuals during higher flow. The systematic difference between the high-flow and low-flow residuals is more likely explained by the change in flow paths during base flow.

[38] Nevertheless, both the results of BC and hydrology comparison combined support the concept that the stream dynamics are controlled by variable source areas [Creed and Band, 1998]. This shows that groundwater and surface water interaction is paramount for understanding stream biogeochemistry in catchments of these scales [Garrett et al., 2012]. Additionally, this explains how larger rivers continue discharging during base flow when smaller streams dry up. The question remains whether the large proportion of deep groundwater during base flow is common for catchments of this size or if our study catchment is a special case? An esker passes through the study catchment (Figure 1) which potentially could provide a continuous supply of deeper groundwater that feed into the stream during base flow. It is plausible that the influx of deep groundwater could be less if the stream only drained till soils instead of the more permeable sorted sediments in the valley. However, our results are consistent with previous findings of Capell et al. [2011], Wu et al. [2004], Shaman et al. [2004], and Ladouche et al. [2000] who also showed that deep groundwater dominates discharge during base flow in mesoscale catchments. This suggests that the importance of changing hydrological pathways is likely a more generalizable scale process.

[39] Future DOC research should therefore include more focus on understanding the role of changing water flow paths in catchment of these scales. Understanding spatial and temporal variability of deep groundwater is one-step forward toward gaining new insights of stream biogeochemistry regulation during base flow. Understanding the role of water pathways has strong implications for river resource management especially in terms of controlling pollution spread [Dunn et al., 2012], monitoring groundwater extraction [Genereux et al., 2013; Tague et al., 2007], and developing sustainable management strategies [Smerdon et al., 2012].

\section{Conclusion}

[40] In this study, we present a step forward to understanding how catchment functions at the mesoscale. The research suggests that deep groundwater input rather than in-stream processes are more justifiable at explaining DOC variability within the study catchment. We highlighted the importance of changing hydrological pathways for determining stream biogeochemistry by investigating the effects 
of deep groundwater and shallow groundwater interaction on stream DOC concentrations, allowing for uncertainty in the assumptions of the analysis. We showed that during high- and intermediate-flow conditions, shallow groundwater that drains the upland landscape determines stream chemistry. During low flow, our results demonstrate that deep groundwater has larger influence on stream chemistry than shallow groundwater. The results from this study provide a conceptual model of the hydrological functioning of stream and river DOC regulation that can lead to the improved understanding of how biogeochemistry in mesoscale catchments is controlled.

[41] Acknowledgments. This study is a part of the Krycklan Catchment Study (KCS) which is funded by the Swedish Research Council, Formas, ForWater, Future Forests, SKB, and Kempe Foundation and involves many skilled, helpful scientists and students. Particular thanks go to the Krycklan crew for excellent field and laboratory support.

\section{References}

Ågren, A., I. Buffam, M. Jansson, and H. Laudon (2007), Importance of seasonality and small streams for the landscape regulation of dissolved organic carbon export, J. Geophys. Res., 112, G03003, doi:10.1029/ 2006JG000381.

Ågren, A., I. Buffam, K. Bishop, and H. Laudon (2010), Modeling stream dissolved organic carbon concentrations during spring flood in the borea forest: A simple empirical approach for regional predictions, J. Geophys. Res., 115, G01012, doi:10.1029/2009JG001013.

Ågren, A. M., I. Buffam, D. M. Cooper, T. Tiwari, C. D. Evans, and H. Laudon (2013), Can the heterogeneity in stream dissolved organic carbon be explained by contributing landscape elements?, Biogeosci. Discuss., 10, 15,913-15,949, doi:10.5194/bgd-10-15913-2013.

Aitkenhead, J. A., D. Hope, and M. F. Billett (1999), The relationship between dissolved organic carbon in stream water, Hydrol. Processes, 13(8), 1289-1302, doi:10.1002/(SICI)1099-1085(19990615)13:8< 1289: :AID-HYP766>3.0.CO;2-M.

Benner, R., and S. Opsahl (2001), Molecular indicators of the sources and transformation of dissolve organic matter in the Mississippi river plume, Org. Geochem., 32, 597-611.

Berggren, M., H. Laudon, A. Jonsson, and M. Jansson (2010), Nutrient constraints on metabolism affect the temperature regulation of aquatic bacterial growth efficiency, Microb. Ecol., 60(4), 894-902, doi:10.1007/ s00248-010-9751-1.

Bertilsson, S., and L. J. Tranvik (2000), Photochemical transformation of dissolved organic matter in lakes, Limnol. Oceanogr., 45(4), 753-762.

Bishop, K., J. Seibert, S. Köhler, and H. Laudon (2004), Resolving the double paradox of rapidly mobilized old water with highly variable responses in runoff chemistry, Hydrol. Processes, 18(1), 185-189, doi: 10.1002/hyp.5209.

Bracken, L. J., and J. Croke (2007), The concept of hydrological connectivity and its contribution to understanding runoff-dominated geomorphic systems, Hydrol. Processes, 21(13), 1749-1763, doi:10.1002/hyp.6313.

Brooks, P. D., D. M. McKnight, and K. E. Bencala (1999), The relationship between soil heterotrophic activity, soil dissolved organic carbon (DOC) leachate, and catchment-scale DOC export in headwater catchments, Water Resour. Res., 35(6), 1895-1902.

Buffam, I., H. Laudon, J. Temnerud, C.-M. Mörth, and K. Bishop (2007), Landscape-scale variability of acidity and dissolved organic carbon during spring flood in a boreal stream network, J. Geophys. Res., 112, G01022, doi:10.1029/2006JG000218.

Buffam, I., H. Laudon, J. Seibert, C. M. Mörth, and K. Bishop (2008), Spatial heterogeneity of the spring flood acid pulse in a boreal stream network, Sci. Total Environ., 407(1), 708-722, doi:10.1016/ j.scitotenv.2008.10.006.

Burns, D. A., R. P. Hooper, J. J. McDonnell, J. E. Freer, C. Kendall, and K. Beven (1998), Base cation concentrations in subsurface flow from a forested hillslope: The role of flushing frequency, Water Resour. Res., 34(12), 3535-3544.

Capell, R., D. Tetzlaff, I. A. Malcolm, A. J. Hartley, and C. Soulsby (2011), Using hydrochemical tracers to conceptualise hydrological function in a larger scale catchment draining contrasting geologic provinces, $J$. Hydrol., 408(1-2), 164-177, doi:10.1016/j.jhydrol.2011.07.034.
Catalán, N., B. Obrador, C. Alomar, and J. L. Pretus (2012), Seasonality and landscape factors drive dissolved organic matter properties in Mediterranean ephemeral washes, Biogeochemistry, 112(1-3), 261-274, doi: 10.1007/s10533-012-9723-2.

Cey, E. E., D. L. Rudolph, G. W. Parkin, and R. Aravena (1998), Quantifying groundwater discharge to a small perennial stream in southern Ontario, Canada, J. Hydrol., 210(1-4), 21-37, doi:10.1016/s00221694(98)00172-3

Cole, J. J., et al. (2007), Plumbing the global carbon cycle: Integrating inland waters into the terrestrial carbon budget, Ecosystems, 10(1), 171184, doi:10.1007/s10021-006-9013-8.

Cooper, D. M., A. Jenkins, R. Skeffington, and B. Gannon (2000), Catchment-scale simulation of stream water chemistry by spatial mixing: Theory and application, J. Hydrol., 233(1-4), 121-137, doi:10.1016/ S0022-1694(00)00230-4.

Covino, T. P., and B. L. McGlynn (2007), Stream gains and losses across a mountain-to-valley transition: Impacts on watershed hydrology and stream water chemistry, Water Resour. Res., 43, W10431, doi:10.1029/ 2006WR005544.

Creed, I. F., and L. E. Band (1998), Export of nitrogen from catchments within a temperate forest: Evidence for a unifying mechanism regulated by variable source area dynamics, Water Resour. Res., 34(11), 3105-3120.

Creed, I. F., F. D. Beall, T. A. Clair, P. J. Dillon, and R. H. Hesslein (2008), Predicting export of dissolved organic carbon from forested catchments in glaciated landscapes with shallow soils, Global Biogeochem. Cycles, 22, GB4024, doi:10.1029/2008GB003294.

Docherty, K. M., K. C. Young, P. A. Maurice, and S. D. Bridgham (2006), Dissolved organic matter concentration and quality influences upon structure and function of freshwater microbial communities, Microb. Ecol., 52(3), 378-388, doi:10.1007/s00248-006-9089-x.

Dunn, S. M., C. Birkel, D. Tetzlaff, and C. Soulsby (2010), Transit time distributions of a conceptual model: Their characteristics and sensitivities, Hydrol. Processes, 24(12), 1719-1729, doi:10.1002/Hyp.7560.

Dunn, S. M., W. G. Darling, C. Birkel, and J. R. Bacon (2012), The role of groundwater characteristics in catchment recovery from nitrate pollution, Hydrol. Res., 43(5), 560-575, doi:10.2166/Nh.2012.020.

Estapa, M. L., and L. M. Mayer (2010), Photo-oxidation of particulate organic matter, carbon/oxygen stoichiometry, and related photoreactions, Mar. Chem., 122(1-4), 138-147, doi:10.1016/j.marchem.2010.06.003.

Evans, C. D., D. M. Cooper, S. Juggins, A. Jenkins, and D. Norris (2006), A linked spatial and temporal model of the chemical and biological status of a large, acid-sensitive river network, Sci. Total Environ., 365(1-3), 167-185, doi:10.1016/j.scitotenv.2006.02.037.

Farjalla, V. F., A. M. Amado, A. L. Suhett, and F. Meirelles-Pereira (2009), DOC removal paradigms in highly humic aquatic ecosystems, Environ Sci. Pollut. Res. Int., 16(5), 531-538, doi:10.1007/s11356-009-0165-x.

Findlay, S. E. G., R. L. Sinsabaugh, W. V. Sobczak, and M. Hoostal (2003), Metabolic and structural response of hyporheic microbial communities to variations in supply of dissolved organic matter, Limnol. Oceanogr. Methods, 48(4), 1608-1617.

Frost, P. C., J. H. Larson, C. A. Johnston, K. C. Young, P. A. Maurice, G. A. Lamberti, and S. D. Bridgham (2006), Landscape predictors of stream dissolved organic matter concentration and physicochemistry in a Lake Superior river watershed, Aquat. Sci., 68(1), 40-51, doi:10.1007/s00027005-0802-5.

Garrett, C. G., V. M. Vulava, T. J. Callahan, and M. L. Jones (2012), Groundwater-surface water interactions in a lowland watershed: Source contribution to stream flow, Hydrol. Processes, 26(21), 3195-3206, doi: 10.1002/Hyp.8257.

Genereux, D. P., L. A. Nagy, C. L. Osburn, and S. F. Oberbauer (2013), A connection to deep groundwater alters ecosystem carbon fluxes and budgets: Example from a Costa Rican rainforest, Geophys. Res. Lett., 40, 2066-2070, doi:10.1002/grl.50423.

González-Pinzón, R., R. Haggerty, and M. Dentz (2013), Scaling and predicting solute transport processes in streams, Water Resour. Res., 49 , 4071-4088, doi:10.1002/wrcr.20280.

Grabs, T., K. Bishop, H. Laudon, S. W. Lyon, and J. Seibert (2012), Riparian zone hydrology and soil water total organic carbon (TOC): Implications for spatial variability and upscaling of lateral riparian TOC exports, Biogeosciences, 9(10), 3901-3916, doi:10.5194/bg-9-3901-2012.

Graneli, W., M. Lindell, and L. Tranvik (1996), Photo-oxidative production of dissolved inorganic carbon in lakes of different humic content, Limnol. Oceanogr., 41(4), 698-706.

Hagedorn, F., P. Schleppi, P. Waldner, and H. Fluehler (2000), Export of dissolved organic carbon and nitrogen from Gleysol dominated 
catchments-The significance of water flow paths, Biogeochemistry, 50, $137-161$.

Hinton, M. J., S. L. Schiff, and M. C. English (1998), Sources and flowpaths of dissolved organic carbon during storms in two forested watersheds of the Precambrian Shield, Biogeochemistry, 41(2), 175-197.

Hood, E., M. N. Gooseff, and S. L. Johnson (2006), Changes in the character of stream water dissolved organic carbon during flushing in three small watersheds, Oregon, J. Geophys. Res., 111, G01007, doi:10.1029/ 2005JG000082.

Hornberger, G. M., K. E. Bencala, and D. M. Mcknight (1994), Hydrological controls on dissolved organic-carbon during snowmelt in the Snake River near Montezuma, Colorado, Biogeochemistry, 25(3), 147-165, doi: 10.1007/Bf00024390

Hrachowitz, M., C. Soulsby, D. Tetzlaff, and M. Speed (2009), Catchment transit times and landscape controls does scale matter?, Hydrol. Processes, doi:10.1002/hyp.7510.

Hruska, J., S. Kohler, H. Laudon, and K. Bishop (2003), Is a universal model of organic acidity possible: Comparison of the acid/base properties of dissolved organic carbon in the boreal and temperate zones, Environ. Sci. Technol., 37(9), 1726-1730, doi:10.1021/Es0201552.

Jencso, K. G., B. L. McGlynn, M. N. Gooseff, S. M. Wondzell, K. E. Bencala, and L. A. Marshall (2009), Hydrologic connectivity between landscapes and streams: Transferring reach- and plot-scale understanding to the catchment scale, Water Resour. Res., 45, W04428, doi: 10.1029/2008WR007225.

Joerin, C., K. J. Beven, I. Iorgulescu, and A. Musy (2002), Uncertainty in hydrograph separations based on geochemical mixing models, $J$. Hydrol., 255(1-4), 90-106.

Kalbitz, K., and R. Wennrich (1998), Mobilization of heavy metals and arsenic in polluted wetland soils and its dependence on dissolved organic matter, Sci. Total Environ., 209(1), 27-39, doi:10.1016/S00489697(97)00302-1.

Kalbitz, K., D. Schwesig, J. Schmerwitz, K. Kaiser, L. Haumaier, B. Glaser, R. Ellerbrock, and P. Leinweber (2003), Changes in properties of soilderived dissolved organic matter induced by biodegradation, Soil Biol. Biochem., 35(8), 1129-1142, doi:10.1016/S0038-0717(03)00165-2.

Kalbus, E., F. Reinstorf, and M. Schirmer (2006), Measuring methods for groundwater-surface water interactions: A review, Hydrol. Earth Syst. Sci., 10, 873-887.

Klaminder, J., H. Grip, C. M. Morth, and H. Laudon (2011), Carbon mineralization and pyrite oxidation in groundwater: Importance for silicate weathering in boreal forest soils and stream base-flow chemistry, Appl. Geochem., 26(3), 319-324, doi:10.1016/j.apgeochem.2010.12.005.

Köhler, S., I. Buffam, A. Jonsson, and K. Bishop (2002), Photochemical and microbial processing of stream and soilwater dissolved organic matter in a boreal forested catchment in northern Sweden, Aquat. Sci., 64(3), 269-281.

Krause, S., A. Bronstert, and E. Zehe (2007), Groundwater-surface water interactions in a North German lowland floodplain-Implications for the river discharge dynamics and riparian water balance, J. Hydrol., 347(3-4), 404-417, doi:10.1016/j.jhydrol.2007.09.028.

Ladouche, B., A. Probst, D. Viville, A. Idir, M. Loubet, J. L. Probst, and T. Bariac (2000), Hydrograph separation using isotopic, chemical and hydrological, J. Hydrol., 242, 255-274.

Langhoff, J. H., K. R. Rasmussen, and S. Christensen (2006), Quantification and regionalization of groundwater-surface water interaction along an alluvial stream, J. Hydrol., 320(3-4), 342-358, doi:10.1016/ j.jhydrol.2005.07.040.

Larson, J. H., P. C. Frost, D. M. Lodge, and G. A. Lamberti (2007), Photodegradation of dissolved organic matter in forested streams of the northern Great Lakes region, J. North Am. Benthol. Soc., 26(3), 416-425, doi: $10.1899 / 06-097.1$

Laudon, H., and I. Buffam (2008), Impact of changing DOC concentrations on the potential distribution of acid sensitive biota in a boreal stream network, Hydrol. Earth Syst. Sci., 12(2), 425-435.

Laudon, H., S. Köhler, and I. Buffam (2004a), Seasonal TOC export from seven boreal catchments in northern Sweden, Aquat. Sci., 66(2), 223230, doi:10.1007/s00027-004-0700-2.

Laudon, H., J. Seibert, S. Kohler, and K. Bishop (2004b), Hydrological flow paths during snowmelt: Congruence between hydrometric measurements and oxygen 18 in meltwater, soil water, and runoff, Water Resour. Res., 40, W03102, doi:10.1029/2003WR002455.

Laudon, H., M. Berggren, A. Ågren, I. Buffam, K. Bishop, T. Grabs, M. Jansson, and S. Köhler (2011), Patterns and dynamics of dissolved organic carbon (DOC) in boreal streams: The role of processes, connectivity, and scaling, Ecosystems, 14(6), 880-893, doi:10.1007/ s10021-011-9452-8.

Laudon, H., J. Buttle, S. K. Carey, J. McDonnell, K. McGuire, J. Seibert, J. Shanley, C. Soulsby, and D. Tetzlaff (2012), Cross-regional prediction of long-term trajectory of stream water DOC response to climate change, Geophys. Res. Lett., 39, L18404, doi:10.1029/2012GL053033.

Laudon, H., I. Taberman, A. Ågren, M. Futter, M. Ottosson-Löfvenius, and K. Bishop (2013), The Krycklan Catchment Study - A flagship infrastructure for hydrology, biogeochemistry, and climate research in the boreal landscape, Water Resour. Res., 49, 7154-7158, doi:10.1002/ wrcr. 20520

Lyon, S. W., M. Nathanson, A. Spans, T. Grabs, H. Laudon, J. Temnerud, K. H. Bishop, and J. Seibert (2012), Specific discharge variability in a boreal landscape, Water Resour. Res., 48, W08506, doi:10.1029/ 2011WR011073.

Maurice, P. A., S. E. Cabaniss, J. Drummond, and E. Ito (2002), Hydrogeochemical controls on the variations in chemical characteristics of natural organic matter at a small freshwater wetland, Chem. Geol., 187(1-2), 59-77.

Nathanson, M., J. W. Kean, T. J. Grabs, J. Seibert, H. Laudon, and S. W. Lyon (2012), Modelling rating curves using remotely sensed LiDAR data, Hydrol. Processes, 26(9), 1427-1434, doi:10.1002/hyp.9225.

Nippgen, F., B. L. McGlynn, L. A. Marshall, and R. E. Emanuel (2011), Landscape structure and climate influences on hydrologic response, Water Resour. Res., 47, W12528, doi:10.1029/2011WR011161.

Oni, S. K., M. N. Futter, K. Bishop, S. J. Köhler, M. Ottosson-Löfvenius, and H. Laudon (2013), Long-term patterns in dissolved organic carbon, major elements and trace metals in boreal headwater catchments: Trends, mechanisms and heterogeneity, Biogeochemistry, 10, 23152330, doi:10.5194/bg-10-2315-2013.

Pacific, V. J., K. G. Jencso, and B. L. McGlynn (2010), Variable flushing mechanisms and landscape structure control stream DOC export during snowmelt in a set of nested catchments, Biogeochemistry, 99(1-3), 193211, doi:10.1007/s10533-009-9401-1.

Payn, R. A., M. N. Gooseff, B. L. McGlynn, K. E. Bencala, and S. M. Wondzell (2012), Exploring changes in the spatial distribution of stream baseflow generation during a seasonal recession, Water Resour. Res., 48 , W04519, doi:10.1029/2011WR011552.

Reinthaler, T., C. Winter, and G. J. Herndl (2005), Relationship between bacterioplankton richness, respiration, and production in the Southern North Sea, Appl. Environ. Microbiol., 71(5), 2260-2266, doi:10.1128/ AEM.71.5.2260-2266.2005.

Schmidt, S. I., and H. J. Hahn (2012), What is groundwater and what does this mean to fauna?-An opinion, Limnologica-Ecol. Manage. Inland Waters, 42(1), 1-6, doi:10.1016/j.limno.2011.08.002.

Shaman, J., M. Stieglitz, and D. Burns (2004), Are big basins just the sum of small catchments?, Hydrol. Processes, 18(16), 3195-3206, doi: 10.1002/hyp.5739.

Smerdon, B. D., W. Payton Gardner, G. A. Harrington, and S. J. Tickell (2012), Identifying the contribution of regional groundwater to the baseflow of a tropical river (Daly River, Australia), J. Hydrol., 464-465, 107-115, doi:10.1016/j.jhydrol.2012.06.058.

Sobczak, W. V., L. O. Hedin, and M. J. Klug (1998), Relationships between bacterial productivity and organic carbon at a soil-stream interface, Hydrobiologia, 386, 45-53, doi:10.1023/A:1003583813445.

Soulsby, C., and S. M. Dunn (2003), Towards integrating tracer studies in conceptual rainfall-runoff models: Recent insights from a sub-arctic catchment in the Cairngorm Mountains, Scotland, Hydrol. Processes, 17(2), 403-416, doi:10.1002/Hyp.1132.

Soulsby, C., K. Piegat, J. Seibert, and D. Tetzlaff (2011), Catchment-scale estimates of flow path partitioning and water storage based on transit time and runoff modelling, Hydrol. Processes, 25(25), 3960-3976, doi: 10.1002/Hyp.8324.

Tague, C., G. Grant, M. Farrell, J. Choate, and A. Jefferson (2007), Deep groundwater mediates streamflow response to climate warming in the Oregon Cascades, Clim. Change, 86(1-2), 189-210, doi:10.1007/ s10584-007-9294-8.

Tetzlaff, D., J. J. McDonnell, S. Uhlenbrook, K. J. McGuire, P. W. Bogaart, F. Naef, A. J. Baird, S. M. Dunn, and C. Soulsby (2008), Conceptualizing catchment processes: Simply too complex?, Hydrol. Processes, 22(11), 1727-1730, doi:10.1002/Hyp.7069.

Tetzlaff, D., S. K. Carey, H. Laudon, and K. McGuire (2010), Catchment processes and heterogeneity at multiple scales-benchmarking observations, conceptualization and prediction Preface, Hydrol. Processes, 24(16), 2203-2208, doi:10.1002/Hyp. 7784. 


\section{TIWARI ET AL. : DOWNSTREAM CHANGES IN DOC}

Tranvik, L. J., and S. Bertilsson (2001), Contrasting effects of solar UV radiation on dissolved organic sources for bacterial growth, Ecol. Lett., 4(5), 458-463.

Uhlenbrook, S., M. Frey, C. Leibundgut, and P. Maloszewski (2002), Hydrograph separations in a mesoscale mountainous basin at event and seasonal timescales, Water Resour. Res., 38(6), 1096, doi:10.1029/ 2001WR000938.

Wallin, M. B., T. Grabs, I. Buffam, H. Laudon, A. Ågren, M. G. Öquist, and K. Bishop (2013), Evasion of CO2 from streams-The dominant component of the carbon export through the aquatic conduit in a boreal landscape, Global Change Biol., 19(3), 785-797, doi:10.1111/gcb.12083.

Wolock, D. M., J. Fan, and G. B. Lawrence (1997), Effects of basin size on low-flow stream chemistry and subsurface contact time in the Neversink River Watershed, New York, Hydrol. Processes, 11(9),
1273-1286, doi:10.1002/(Sici)1099-1085(199707)11:9<1273::Aid-Hyp $557>3.0 . \mathrm{Co} ; 2-\mathrm{S}$.

Wu, Y., X. Wen, and Y. Zhang (2004), Analysis of the exchange of groundwater and river water by using Radon-222 in the middle Heihe Basin of northwestern China, Environ. Geol., 45(5), 647-653, doi:10.1007/ s00254-003-0914-y.

Xie, H. X., O. C. Zafiriou, W. J. Cai, R. G. Zepp, and Y. C. Wang (2004), Photooxidation and its effects on the carboxyl content of dissolved organic matter in two coastal rivers in the Southeastern United States, Environ. Sci. Technol., 38(15), 4113-4119.

Ziegler, S. E., and S. L. Brisco (2004), Relationships between the isotopic composition of dissolved organic carbon and its bioavailability in contrasting Ozark streams, Hydrobiologia, 513(1-3), 153-169, doi: 10.1023/B:hydr.0000018180.54292.47. 